\title{
Harry Harlow: From the Other Side of the Desk
}

\author{
Helen A. LeRoy
}

Published online: 27 August 2008

C The Author(s) 2008. This article is published with open access at Springerlink.com

\begin{abstract}
On the basis of her personal reminiscences the author provides a picture of Harry Harlow's personality. Harlow emerges as an unassuming and witty person.
\end{abstract}

Keywords History of psychology $\cdot$ Biography $\cdot$ Harlow

I am pleased to have the opportunity to say a few words about the human side of Harry Harlow. I had the privilege of spending a lot of time with Harry Harlow, helping him keep track of his comings and goings. He was an extremely busy man, with an almost surreal out-of-town travel schedule, combined with multiple local obligations. He ran a major primate research laboratory that he had created in the early 1930's. He was a Psychology Professor, one of the most popular professors on the University of Wisconsin campus. In addition, he was heavily recruited as a speaker, to address groups at other colleges and universities and professional societies in many areas of the behavioral sciences, not only psychology. He was an NIH consultant, GRE/Educational Testing Service consultant, American Institutes of Research consultant, on the editorial board of Science, just to name a few of those kinds of roles, Besides that, at the time I met him, Harlow was the Editor of the Journal of Comparative and Physiological Psychology (JCPP), an extremely demanding job, and its operation was in full swing when I arrived at the Primate Lab. And to top that all off, Harlow was President of the American Psychological Association (APA), having just delivered his presidential address on "The Nature of Love" at the annual APA convention in Washington, D.C. in August, where he introduced his audience to the monkey mother surrogates.

It was at that time, in the fall of 1958, that my relationship with Harry Harlow began, just as the surrogate mother was exploding on the science scene. And I subsequently had the opportunity to become his confidante and sit at his side

Dr. Frank C.P. van der Horst (fhorst@fsw.leidenuniv.nl) of Leiden University stands as the person to address correspondence to. 
soaking up his day-to-day comments, observations, and witticisms about a lot of things. Over the years I came to know just how he felt about most of the things that touched his life.

In October, 1958, while a University of Wisconsin student majoring in sociology, I responded to an ad at the Student Employment Service for a part-time clerical helper position at the Library of the Primate Lab. When I walked in the door of the Primate Lab for the first time, I was immediately impressed by the pungent aroma dominating the atmosphere. I thought surely I must be at the zoo. But, the place had a very welcoming and reassuring ambience about it, and I was interviewed and hired at $\$ 1.10$ an hour. I had had some experience in office work, which enhanced my credentials, resulting in an offer to start at 5 cents an hour above the standard starting salary of the day. At the time, the Library served a vital function in the training of Harlow's graduate students. It was open in the evening hours, as well as during the day, always occupied and full of stimulating discussion. It was fascinating to be introduced to psychology and primate behavioral research through the lively conversations of the graduate students, but after about 9 months, I was relocated to become Harry and Margaret Harlows' assistant in the editing of the Journal of Comparative and Physiological Psychology at the other end of the building, where I subsequently resided for the next 44 years.

In my first encounter with Harlow and JCPP, he very emphatically impressed upon me the fact that words prefixed with "non" are not followed by a hyphen, unless followed by a proper noun, e.g., non-American. So, every time I see in print the term "non-human (hyphenated) primate", my blood pressure rises a little. He also clued me in that parentheses should rarely be used in any kind of writing, but especially not in scientific manuscripts. Harlow would say "If it's not worth incorporating into the body of the text, it's not worth including." It was a pet peeve, and Harlow saw red whenever potential JCPP authors would slip in a qualifier describing some aspect of a research study in parentheses. That went for "etc." as well. A letter, not related to JCPP, but to a book manuscript Harlow was reviewing for McGraw-Hill, as their Consulting Editor in Psychology, reflects these pet peeves.

... the manuscript... is so beautifully and simply written, I hate to make any grammatical comments. But, for my money, he uses 'etc.' too often, and often unnecessarily. The same holds true to a lesser degree for parentheses. Aside from these trivia, he has one habit that I don't like. He very frequently uses the word 'lots'- 'lots of,' 'lots more,' everything but 'lots for sale.'

Harlow had been an English major in college, and if he hadn't received a disappointing grade of ' $\mathrm{C}$ ' on an English assignment at Stanford and developed an interest in psychological research, he might very well have become an English professor instead. He even maintained a life-long love for writing poetry, and, as an example, I will insert just a very few lines of representive verse here. They are part of a larger work:

All beasts of every kind and name

Are draped upon a bony frame 
With vertebrae arranged in tiers

\section{Supporting structures for the ears}

Over the years, Harlow received compliments about his writing style from countless individuals, but that would be a whole chapter in itself.

Harry Harlow was a leader, and there was nothing wishy-washy about Harry Harlow. He was totally devoted to his research and his Primate Lab. He was there from early morning until 9 or 10 at night, although he did go home for dinner. He often had early morning coffee with the janitors. He treated his staff, and to some degree his students, as his equals. The students achieved full equality upon completing their Ph.D.s, and then Harlow bent over backwards to help them obtain the best academic jobs possible, and he sent them off with resources in the form of monkeys, apparatus, and encouragement. He was extremely generous along those lines.

In my long professional involvement, it has been my impression that the academic world contains more than its share of faculty type characters who possess generously high opinions of themselves. But not Harlow. He was down-to-earth and unassuming. He never let his fame get in the way of his dealings with those around him. There was not a trace of superiority nor dictatorship in Harlow's management of laboratory personnel. He allowed his graduate students, postdocs, and staff enough latitude to blossom on their own, to try out their own ideas. Many individuals below the level of Ph.D. played major roles in research, administration, and the oversight and operation of the laboratory. The animal-care staff were key in maintaining the excellent care of the monkeys and the successful breeding program, long before the existence of IACUC's and other campus oversight bureaucracies. Harlow felt very strongly about providing the best care possible for the monkeys. Animal caretakers, along with photographer, apparatus makers, secretaries, and monkey testers, were all essential parts of Harlow's staff, and we were a closely-knit family. Harlow was very appreciative of our efforts.

To this day, many of us have maintained strong bonds and enduring friendships. I guess if someone were to ask me what about Harry Harlow impressed me the most, I would surely reply that it was his uncanny ability to bring together some of the greatest people I could ever hope to know. They were from all areas of the country and different parts of the world. We were, indeed, a family.

On the other hand, if I were to name my favorite personality trait, it would be Harry Harlow's sense of humor and his great wit-hands down! I have never known a funnier person. Not only was the time spent with him extremely educational, it was also extremely entertaining. I think Harlow could have given Groucho Marx a run for his money anytime.

Sometimes, Harry Harlow fit perfectly the stereotype of the "absent-minded professor." He could be so wrapped up in his work and thoughts that he was oblivious to what was taking place in his immediate environment. Harlow was a cigarette smoker, and I puffed up a storm right along with him. He had a habit of lighting a cigarette, flicking the match, and dropping it into a nearby ashtray or wastebasket. Frequently the match was still lit. He did not look at it to make sure it had gone out. He simply flicked his wrist and tossed the match. One afternoon, he 
was having me write down a series of ideas he had about a manuscript. I was writing away at a frantic pace when I suddenly smelled smoke and looked over to see a merry blaze escalating in his wastebasket, half full of paper. I quickly grabbed both our cups of coffee, doused the fire, and carried the smoldering basket out into the hall. Harlow did not bat an eye. In fact, he did not stop talking during the entire episode. As I was moving about, I was still listening to him. I resumed my chair, lifted my pen, and we kept right on, without missing a beat.

Now, this smoking habit did not go unnoticed. In March, 1962, following a nationally broadcast appearance on network television, Harlow received a letter from a concerned woman in Michigan, who let him have it:

Dear Sir: Some weeks ago I watched your television program on your experiment on the monkey. It was truly interesting. I have been impressed to write to you, in that I belong to the American Temperance Society, and after watching the program, I found myself not feeling so sorry for the unloved baby monkey as I was for you, Mr. Harlow. The tobacco companies must feel proud when they watch television and see educated men like you smoke during the program, light one cigarette after another. Their experiment truly is a success as far as they are concerned. They have made a tobacco slave of you. In all sincerity, you too should experiment on giving up that filthy habit that is ruining your health - it has been proved and proved to your fellow man that it can be done. Most sincerely.

Harlow was not a procrastinator - at anything. All incoming correspondence was answered almost immediately. He replied to this woman several days later, replying cordially that:

Dear Mrs.: Thank you very much for your letter of March 15, 1962, and I am in complete agreement with you that it is improper for a scientist to smoke, and certainly not chain smoke, on a live television program. This is an evil habit and everything possible should be done to prevent children from falling victim to the tobacco companies' advertising. We hope, of course, that some day somebody will be able to invent a tobacco which is not a menace to human survival. Since I had never spoken before on live television, I was under some tension, so that my smoking habits probably appeared much worse than they really are. Sincerely yours, Harry F. Harlow.

Of course, it probably isn't necessary for me to point out that his smoking habits probably were as bad as they appeared.

When people would encounter Harlow in the hall (as he wore a path to the coffee pot at the other end of it), or in his office, and greet him with "Hi, Dr. Harlow. How are you?" his frequent reply, somewhat quizzically, would be "I often wonder." When he was surprised by something he had just heard or read, he would a emit a startled high-pitched "eek!" When it was something that really disturbed him, he would shudder and almost simultaneously utter a low, rumbling "whoosh!", reminiscent of thunder in the distance.

The man could simply not just sit down and do nothing. His pen, coffee cup, and cigarettes were such an integral part of his physical being. The coffee cups and 
cigarettes are gone, but the effects of the pen are still present. One of my favorite letters arrived in 1990, quite some time after Harlow's death, from a graduate student at Dartmouth Medical School. An excerpt follows:

As a physiologist, I usually find the reading of psychology articles and texts to be an uninteresting task which I do only of necessity. (Of course, I find dry, obscure tomes discussing neuropeptides to be extremely fascinating.) That is, however, until I happened upon this collection of writings by Harlow. Herein I have found more than just intelligent hypotheses brought to compelling results through elegant experimental work. I have also found a wealth of enjoyment in its humor and unpretentious direct tone. I wish that all science were presented in such a pleasant and engaging fashion. I am as yet a beginner in the world of science. In reading these papers I am encouraged to develop the kind of writing skill that makes reading fun and science more than just information.... if you have contact with any of his other staff or family members, please let them know how Harlow's life work is still inspiring new scientists today. Sincerely.

Harlow received hundreds of letters from people of all ages and in all walks of life asking him what he thought about a variety of things. And he didn't shove them aside. He dealt with them thoughtfully and replied promptly. This is easily affirmed in noting the dates appearing on the correspondence, both received and replied. Harlow did not procrastinate, and he did not brush anyone off. I think anyone familiar with this collection would agree that Harlow's responses went beyond the average of a cursory acknowledgement, or a note accompanied by reprints, or no response at all. The individuals who initiated the exchanges might not have been scientific colleagues nor peers, but they were interested, asked questions, and their questions were addressed and responded to within a week.

Harry Harlow had an extremely tough time before, at the time, and shortly after his wife Peggy (Margaret Kuenne Harlow) died of cancer on August 11, 1971. He was absolutely devastated. The family had been facing this prospect ever since Peggy's cancer was diagnosed in the summer of 1966 and she had been hospitalized periodically at UW Hospitals and subjected to heavy sessions of chemotherapy. Harry and Clara, his first wife, who was then living in Knoxville, Tennessee, were reunited not too long after and were subsequently remarried in March of 1972. From that time forward, Harlow took great delight in introducing Clara as his "first and last wife," a title she relished and enjoyed in good humor. But during the intervening period, Harlow suffered from a serious depression, and we were greatly concerned. After their remarriage, Clara moved to Madison, and our Lab family enjoyed meeting her and welcoming her into our midst. Harry Harlow wrote one of his verses for Clara, and I have reproduced it here:

Living Love (written for Clara, early 1972)

Our first attempt at love is past

We trust the second love will last

A longer time, more deep and clear 
With feelings warm and memories dear.

The love we lost is not a debt

Nothing remains we can regret

The years we lost have come and gone

To leave us free to carry on.

We do not cry for time now dead

When all of life lies fast ahead

We thank the fates that let us care

A last eternity to share.

Because Clara suffered from asthma, made worse by the Wisconsin climate, and partly because his own health was deteriorating, Harry Harlow resigned as Director of the Wisconsin Primate Lab in 1974, and he and Clara moved to Tucson, Arizona, where former graduate student, Jim King, was a University of Arizona faculty member in Psychology. They enjoyed condominium living, with a street address on Roller Coaster Road. Their street address in Tucson was almost as interestingly named as their previous address in Madison, Wisconsin—on Grand Canyon Drive. I think Harry Harlow found that amusing. And that was good, because I know he was suffering from "separation anxiety" and saddened at having had removed himself from his beloved lab. His departure was tough for all of us. Things have never been the same.

Open Access This article is distributed under the terms of the Creative Commons Attribution Noncommercial License which permits any noncommercial use, distribution, and reproduction in any medium, provided the original author(s) and source are credited.

Helen A. LeRoy recently retired from the Harlow Primate Lab at the University of Wisconsin-Madison after working there for nearly half a century. During that time, she worked closely with Harry Harlow from her arrival in 1958 until his retirement in 1974. She was Harlow's executive assistant and was his help and stay in the editing of the Journal of Comparative and Physiological Psychology. 